\begin{tabular}{|c|c|c|}
\hline \multirow{2}{*}{ Fi } & $\begin{array}{l}\text { International Journal of Current Research in } \\
\text { Biosciences and Plant Biology }\end{array}$ & \\
\hline & Volume 5 • Number 6 (June-2018) • ISSN: 2349-8080 (Online) & \\
\hline $\begin{array}{l}\text { EXCELLENT } \\
\text { PUBLISHERS }\end{array}$ & Journal homepage: www.ijcrbp.com & \\
\hline
\end{tabular}

\title{
Ten Previously Unreported Basidiomycota Macrofungi from Salahadin Governorate Including Five New Records to Iraq
}

\author{
Talib O. Al-Khesraji* \\ Department of Biology, College of Education for Pure Sciences, Tikrit University, Iraq \\ ${ }^{*}$ Corresponding author.
}

\begin{tabular}{ll}
\hline Article Info & A BS TRACT \\
\hline Date of Acceptance: & Macrofungi specimens were collected from Tikrit and Dujail districts of Salahadin \\
09 May 2018 & $\begin{array}{l}\text { Governorate (North Central Iraq) between 2017 and 2018. Ten Basidiomycota } \\
\text { macrofungal species (Agrocybe praecox, Clitocybe flavidella, Conocybe deliquescens, }\end{array}$ \\
$\begin{array}{l}\text { Date of Publication: } \\
\text { C6 June } 2018\end{array}$ & $\begin{array}{l}\text { Coprinopsis romagnesiana, Lentinus tigrinus, Panaeolus papilionaceus, Parasola plicatilis, } \\
\text { genera, } 6 \text { families and } 2 \text { orders were recorded. Five of these species are new to }\end{array}$ \\
\hline Keyw ords & $\begin{array}{l}\text { macromycota of Iraq. Macroscopic and microscopic characteristics of the recorded } \\
\text { fungal taxa are given. }\end{array}$ \\
\hline $\begin{array}{l}\text { Agaricales } \\
\text { Macrofungi }\end{array}$ & \\
Basidiomycota & \\
Polyporales &
\end{tabular}

\section{Introduction}

Macrofungi (or macromycetes) are fungi that produce fruiting bodies visible to naked eye (Mueller et al., 2007) and can also be defined as fungi that form macroscopic fruiting bodies (Hawksworth et al., 1995; Bates, 2006) or fungi with fruiting bodies greater than one centimeter in diameter (Redhead, 1997). Mushrooms, puffballs, stinkhorns, bracket fungi, toadstools, coral fungi and truffles are well known examples of macrofungi. Most macrofungi are included in Basidiomycota or Ascomycota (Mueller et al., 2007). These fungi are saprobic or mutualistic but few species are plant pathogens (Devi and Shrivastava, 2016). Macrofungi are among the most important organisms on the planet (Mueller and Bills, 2004). They perform a vital role in both agro and natural ecosystems (Ex.: in cycling of nutrients, decomposing of plant and animal remains, as biofertilizers and in bioremediation) (Redhead, 1997; Gadd, 2001). Beside of this, they are used as food, medicine and sources of pharmaceutical active compounds (Redhead, 1997; Chang and Miles, 2004; De Silva et al., 2013).

Salahadin Governorate (North Central Iraq / North of Baghdad, the capital of Iraq) is one of the most 
rural province in Iraq and the arable land covers half of the governorate total area $\left(24,751 \mathrm{Km}^{2}\right)$. It is divided into 8 districts (Al-Shirkat, Al-daur, Baiji, Balad, Dujail, Samaraa, Tikrit and Tooz). Topography of this governorate includes foothills in north eastern parts and desert and steppe in southwest. Most of southwest parts of the governorate receive low levels of precipitation (175-225mm per year) but more precipitation occurs in hilly areas $(250-350 \mathrm{~mm}$ per year). So, agriculture in the governorate depends on irrigation from Tigris River. Salahadin province is rich in vegetation, including tree species (like Salix sp., Populus spp., Pinus sp. and several fruit trees species) with various shrub and herb species. This vegetation richness is expected to harbour a wide variety of macrofungi. Information on these fungi from Salahadin Governorate is very poor, thus the aim of this study was to identify and document the macrofungi present in two districts (Dujail and Tikrit) from Salahadin Governorate and to provide a new contribution to Iraqi macromycota.

\section{Materials and methods}

The macrofungi specimens were collected from
Dujail $\left(33^{0} 51^{\prime} 0^{\prime \prime} \mathrm{N} 44^{0} 14^{\prime} 0^{\prime \prime}\right.$ / $65 \mathrm{Km}$ North Baghdad) and Tikrit $\left(34^{0} 36^{\prime} 36^{\prime \prime} N 43^{0} 40^{\prime} 48^{\prime \prime}\right.$ / 180 $\mathrm{Km}$ North Baghdad) districts of Salahadin Governorate (Fig. 1), between 2017 and 2018. The fungal specimens were photographed in their natural habitat and necessary data on habit, habitat, locality and season were recorded. Macroscopic (such as colour, size and surface texture of the cap, spore print, gills colour, spacing, attachment to stipe, size, colour and surface texture of the stipe and presence or absence of volva and annulus) and microscopic (such as basidium size, number of spores per basidium, spore size and size and shape of cystidia if present) features were reported. Cotton blue in lactophenol and 3\% $\mathrm{KOH}$ were used for microscopy. Identification of the specimens was accomplished according to relevant literatures, keys and monographs (Richardson and Watling, 1997; Keirle et al., 2004; Noordeloos et al., 2005; Kuo, 2004，2006，2007，2008，2010，2011a-c, 2017; Schafer, 2010; Kaur et al., 2014; Adhikari, 2014; Desjardin et al., 2015; O'Reilly, 2016; Lee et al.,2017; Melzer, 2017; Suliaman et al., 2017). Identified specimens are kept in the Department of Biology, College of Education for Pure Sciences, Tikrit University, Iraq.

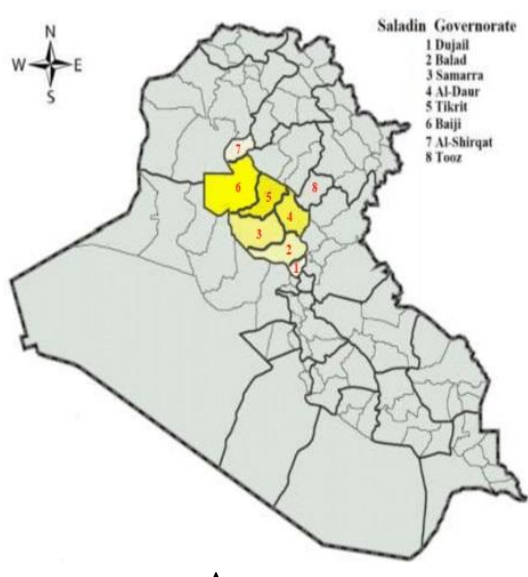

A

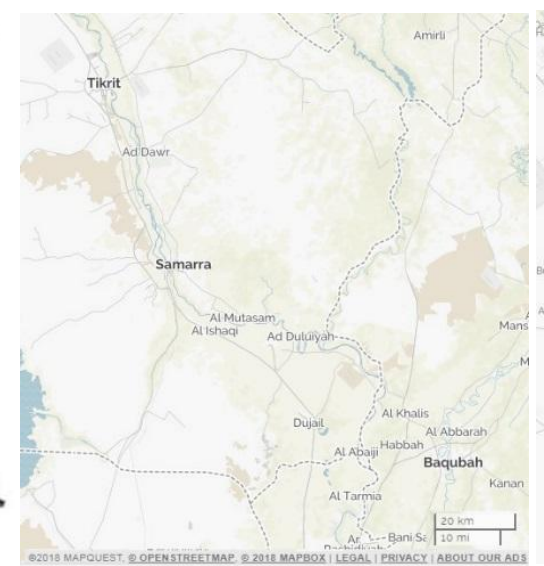

B

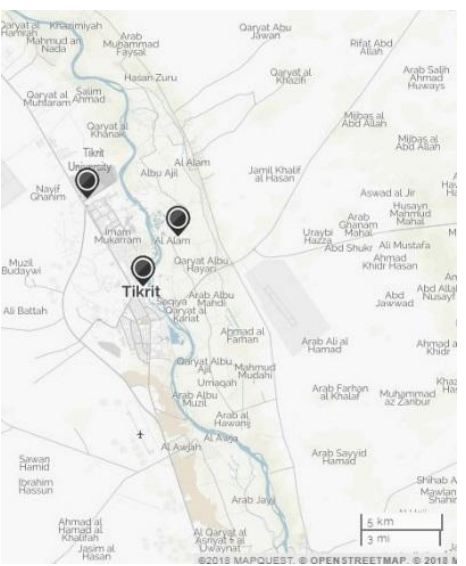

C

Fig. 1: Maps of study area. A, Iraq and districts of Salahadin Governorate ; B, C, study area.

\section{Results and discussion}

Ten Basidiomycota macrofungal species belonging to 9 genera, 6 families and 2 orders (Agrocybe praecox, Clitocybe flavidella, Conocybe deliquescens, Coprinopsis romagnesiana, Lentinus tigrinus, Panaeolus papilionaceus, Parasola plicatilis, Psathyrella candolleana, $\quad P$. spadiceogrisea, and Volvopluteus gloiocephalus) were reported for the first time from Salahadin 
Governorate. Five of these species ( $P$. species are given. papilionaceus, $C$. deliquescens, $C$. flavidella, $C$. romagnesiana, and $P$. plicatilis) are new to Iraqi macromycota. All recorded fungal species are saprotrophic in habitats, five of which (C. flavidella, $C$. romagnesiana, $P$. papilionaceus, $P$. plicatilis and $V$. gloiocephalus) are rarely observed in study area. Below, description and distribution of the identified

$\begin{array}{ll}\text { Kingdom } & \text { : Mycetae } \\ \text { Phylum } & \text { : Basidiomycota } \\ \text { Class } & \text { : Agaricomycetes } \\ \text { Order } & \text { : Agaricales } \\ \text { Family } & \text { : Bolbitiaceae }\end{array}$

Species : Panaeolus papilionaceus

(Bull. ex Fries) Quelet (Fig. 2).
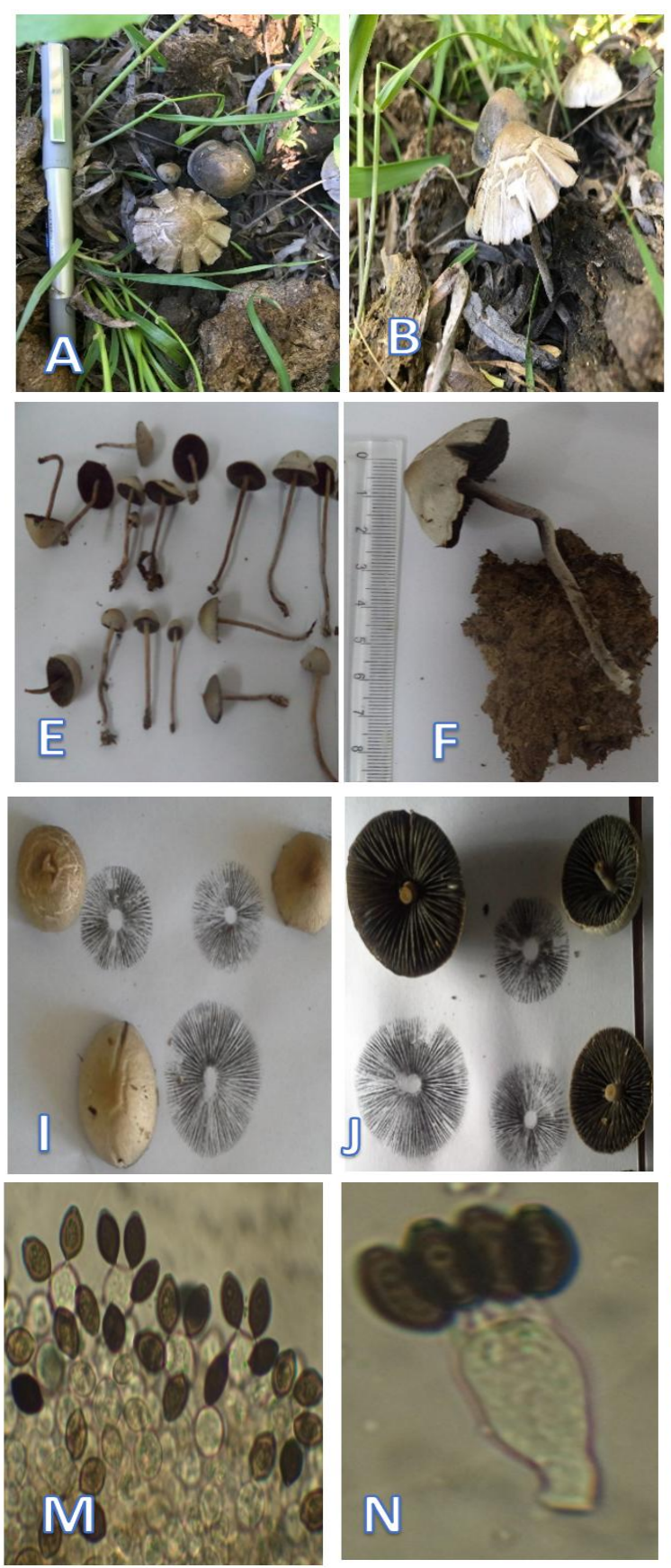
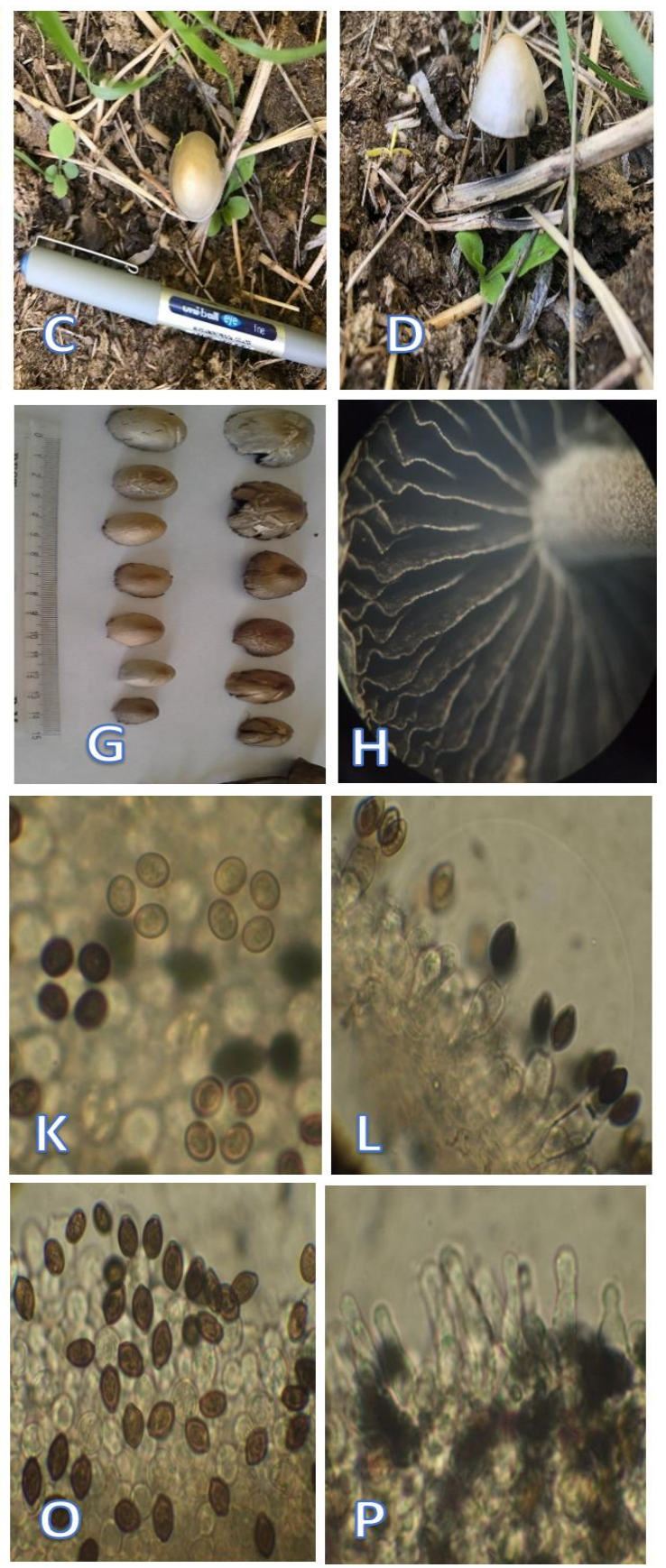

Fig. 2: P. papilionaceus. A-D, fruiting bodies in habitat; $\mathrm{E}-\mathrm{G}$, fruiting bodies in lab.; $\mathrm{H}$, gills; I, J, spore print; K-N, basidia; $\mathrm{O}$, spores; $\mathrm{P}$, cheilocystidia. 
Macroscopic features: Cap: $1-3 \mathrm{~cm}$ across, conical to bell-shaped or hemispherical when young, expanding to broad bell-shaped at age and sometimes cracked at maturity, gray, brown gray or sometimes olive-brown, surface smooth, margin splitting at age. Gills: attached to stipe, crowded or close, unequal, grayish when young then black at maturity, mottled with white edges. Stipe: $3-10 \mathrm{~cm}$ long, $1.5-2.5 \mathrm{~mm}$ thick, cylindric, central, equal, solid, some time enlarged toward the base or apex, white, brown gray or pinkish brown, pruinose. Spore print black.

Microscopic features: Basidia: 25 -37.5 X 12.5$13.5 \mu \mathrm{m}, 4$ - spored, spores 12.5- 15 X 10 - $11.5 \mu \mathrm{m}$, elliptical or lemon-shaped with broad apical germ pore, smooth, black or blackish brown.
Pleurocystidia absent, cheilocystidia many, capitate, clavate, subcylindrical, lageniform. Habit and habitat: singly or gregariously on cow dung; fruiting spring and winter. Al-Efri village / Al-Alam City / Tikrit district. This species occurs on different kinds of dung (horse, camel, donkey, cow) (Gerhardt, 1996; Mohammed et al., 2017). Here is the first detailed report on $P$. papilionacious from Iraq. $P$. papilionaceus was found in Argentina (Niveiro and Alberto, 2012), Europe (O'Reilly, 2016), Guatemala (Florea et al., 2012), India (Amandeep et al., 2015), Nigeria (Mohammed et al., 2017), North America (Kuo, 2007), Greece (Polemis et al., 2012) and Turkey (Sesli and Denchev, 2008).

\section{Species : Conocybe deliquescens Hauskn.} and Krisai. (Fig. 3).
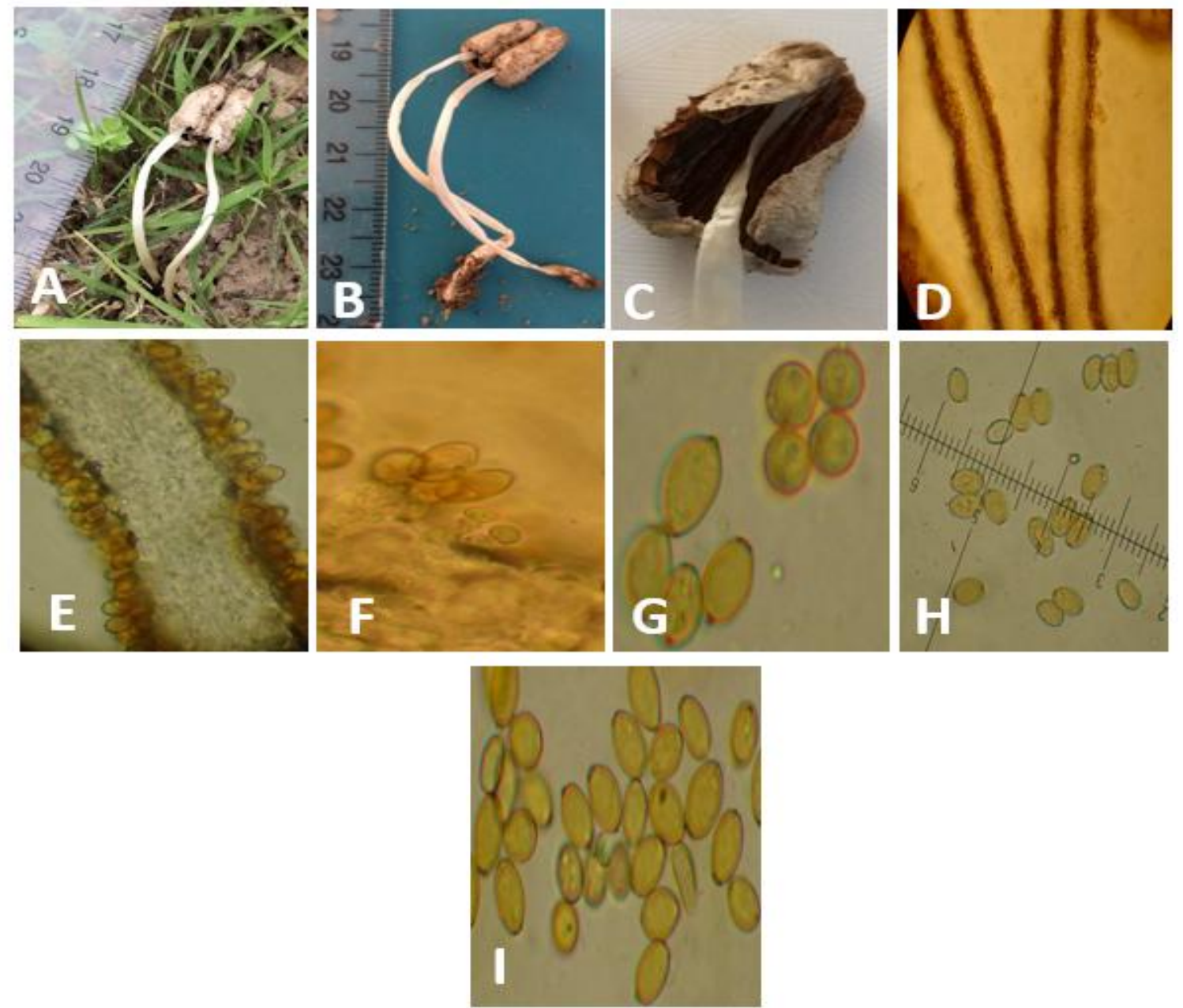

Fig. 3: C. deliquescens. A, fruiting body in habitat; B, C, fruiting body in lab.; D, E, deliquesced gill; F, basidium; G, spores of 4-spored basidium; H, I, spores. 
Macroscopic features: Cap $1-1.5 \mathrm{~cm}$ wide, $0.5-$ $1.5 \mathrm{~cm}$ height, conical to conco- cylindrical, whitish at first, brown to rusty brown in age, smooth, slimy. Gills: whitish when young, becoming brown to rusty brown in age, close, deliquescent. Stipe: up to $8 \mathrm{~cm}$ long, up to $0.3 \mathrm{~cm}$ thick, central, hollow, cylindrical with swollen base, bent at maturity, white.

Microscopic features: Basidia: 4- spored, 25-30 $\times 10-12.5 \mu \mathrm{m}$, spores 8-14 × 6-9 $\mu \mathrm{m}$, ellipsoidal, smooth. Cystidia not distinguished. Habit and habitat: saprotrophic, solitary, grassy areas, gardens. Locality: University campus / Tikrit city / Tikrit district. March-May. This is the first report of $C$. deliquescens from Iraq. The species was reported from Turkey by Sesli and Denchev (2008).

\section{Family : Pluteaceae \\ Species : Volvopluteus gloiocephalus (DC.) \\ Vizzini, Contu \& Justo (Fig. 4).}
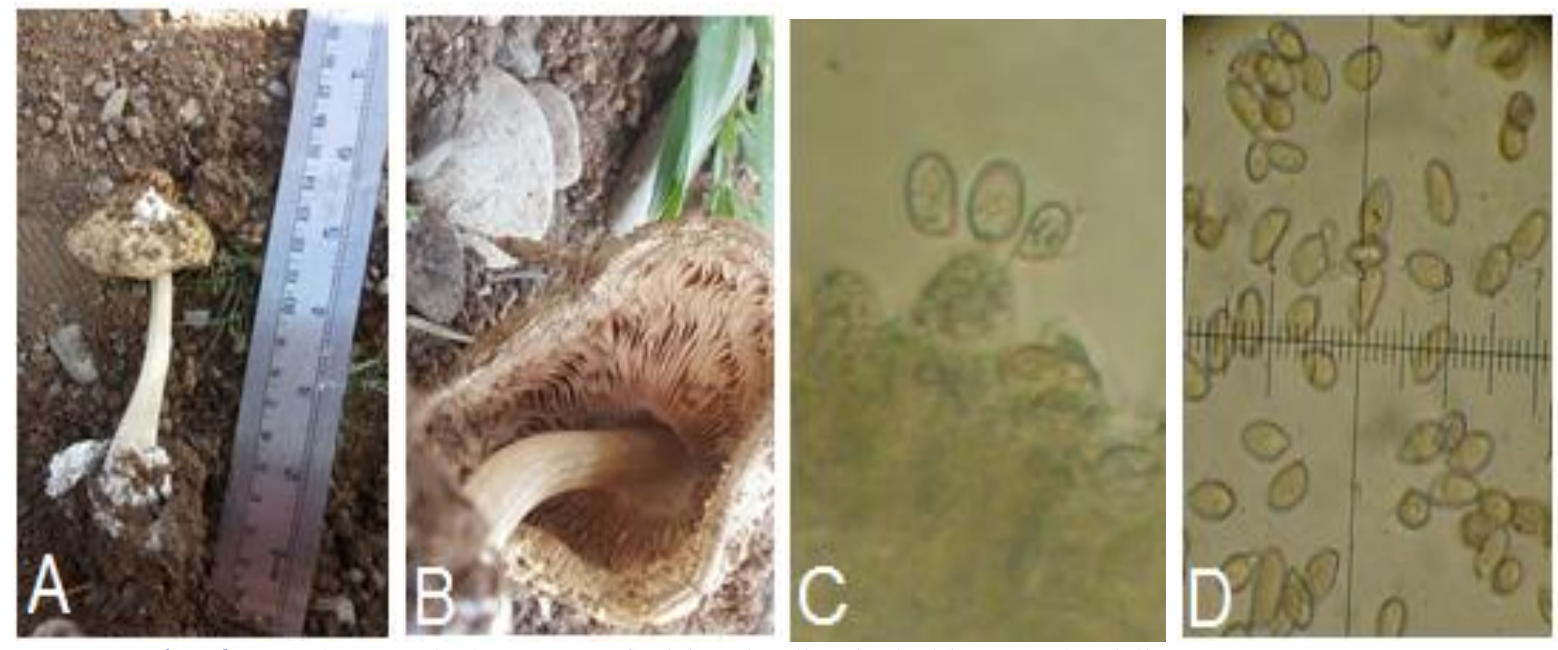

Fig. 4: V. gloiocephalus. A, B, fruiting bodies in habitat; C, basidium; D, spores.

Macroscopic features: Cap $5 \mathrm{~cm}$ across, convex, greyish brown. Gills: white at first, turning pink in age. Stipe: $8 \mathrm{~cm}$ tall, $1 \mathrm{~cm}$ thick, cylindrical with swollen base, central, smooth, volva $1.5 \mathrm{~cm}$ high, saccate, smooth, white.

Microscopic features: Basidia: 4-spored, 35-40 $\times$ 10-15 $\mu \mathrm{m}$, spores ellipsoidal, 10-16 × 7.5-10 $\mu \mathrm{m}$, clamp-connections absent. Habit and habitat: Saprobic, in grassy areas. Locality: University compus / Tikrit district. January- March. This taxon was reported from Northern Iraq by Suliaman et al. (2017) and here is the first report of the fungus from central Iraq (Tikrit district). V. gloiocephalus was found in Europe and North America (Justo et al., 2011), India (Amandeep et al., 2015), Morocco (Ajana et al., 2017), Greece (Polemis et al., 2012) and in some countries bordering Iraq like Turkey (Sesli and Denchev, 2008) and Iran (Fadavi et al., 2015).

\section{Family : Psathyrellaceae}

Species : Coprinopsis romagnesiana (Singer)

Redhead, Vilgalys \& Moncalo (Fig. 5).

Macroscopic features: Cap 3.5- $7 \mathrm{~cm}$ across, ovate at first then to bell-shaped or convex, beige, light brown, with persistent brown scales. Gills: attached to the stem or free, crowded, white turned to black at maturity, deliquesceing at age. Stipe: $6 \mathrm{~cm}$ long, $1 \mathrm{~cm}$ thick, with slightly rimmed bulbous base, central, solid or slightly hallow, white.

Microscopic features: Basidia: 4-spored, 25- 30 $\times 8-10 \mu \mathrm{m}$, spores 8.75-11.25 × 5-6.25 $\mu \mathrm{m}$, elliptical, smooth, orange, reddish brown, hymenial cystidia cylindrical $125 \times 25 \mu \mathrm{m}$. Habit and habitat: saprobic, scattered on stumps under Salix trees. September-December. Defsha village- Al-Alam city / Tikrit district. This is the first record of $C$. romagnesiana from Iraq. This 
fungus was reported from Turkey (Sesli and Denchev, 2008), Korea (Lee et al., 2017), USA
(Kuo, 2008) and Netherlands (Noordeloos et al., 2005).
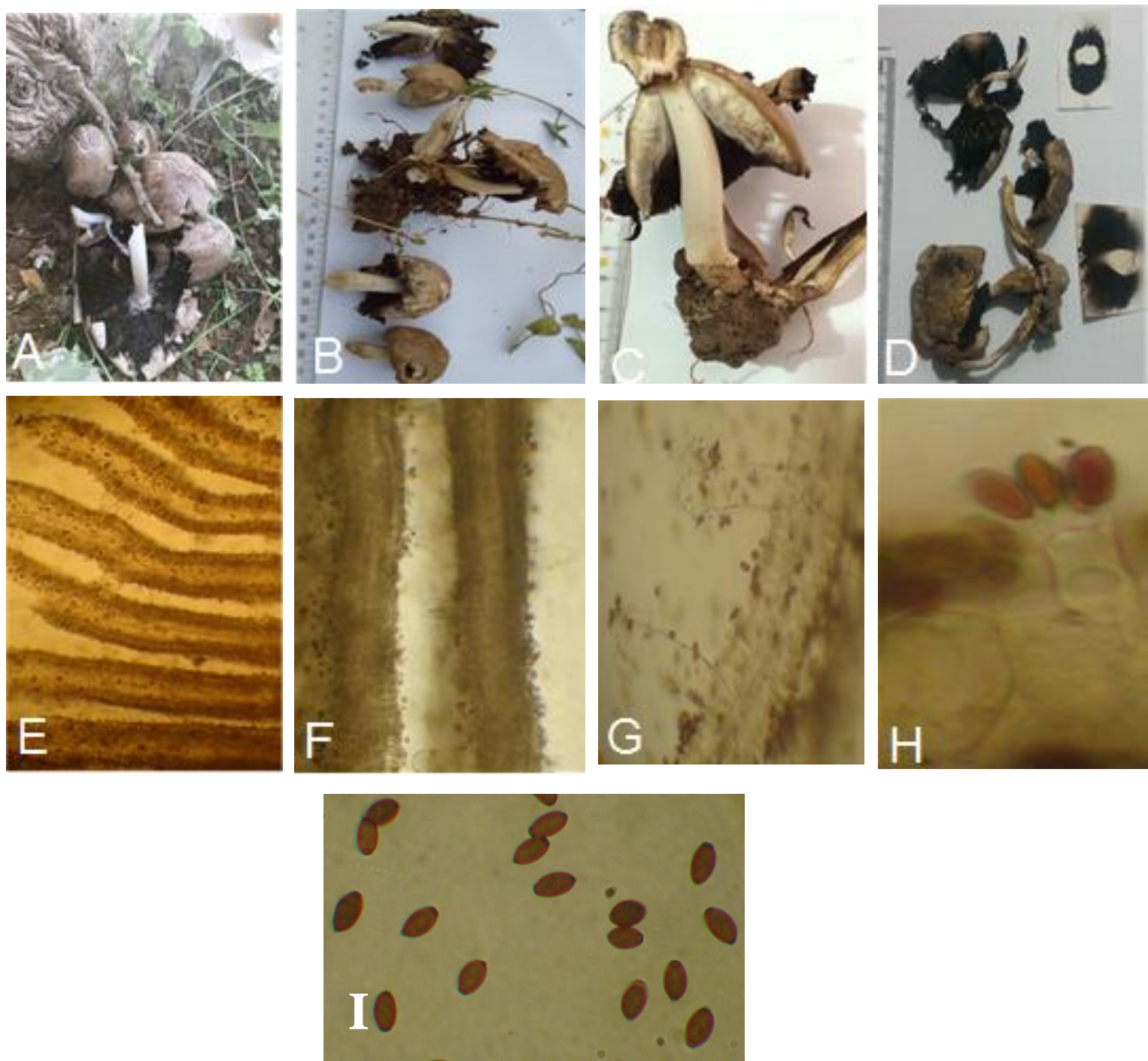

Fig. 5: C. romagnesiana. A, fruiting bodies in habit; B, C, fruiting bodies in lab.; D, spore print; EG, gills and hymenial cystidia; $\mathrm{H}$, basidium; I, spores.

Species: Parasola plicatilis (Curtis) Redhead et al. (Fig. 6).

Macroscopic features: Cap up to $2.5 \mathrm{~cm}$ in diameter, oval at first then convex to flattened or umbrella-like at maturity, with distinctive central brown disc, strongly grooved, gray, gray- metallic, not deliquescent. Gills: free, moderately separated, radiate from a collar around the stipe apex on the underside of the cap, black in age. Stipe: up to $7 \mathrm{~cm}$ tall, white, hollow, equal, fibrillose. Spore print black.
Microscopic features: Basidia: 4-spored, $10 \mu \mathrm{m}$ in diameter (in surface view), spores ellipsoidal, subellipsoid, oblong, subglobose, 8.75- 11.25X 5$8.25 \mu \mathrm{m}$, with eccentric or central germ pore, dark reddish brown. Both cheilocystidia and pleurocystidia widely cylindrical to subcylindrical, $75-100 \times 25-30 \mu \mathrm{m}$. Habit and habitat: short lived saprobic fungus grows singly in roads and gardens. Tikrit city (University campus) / Tikrit district. Autumn-Winter. This is the first report of $P$. plicatilis from Iraq. It is a cosmopolitan species, widely distributed in Europe, North America and 
USA (Keirle et al., 2004; Kuo, 2011; O'Reilly, 2016) and is found also in Argentina (Niveiro and
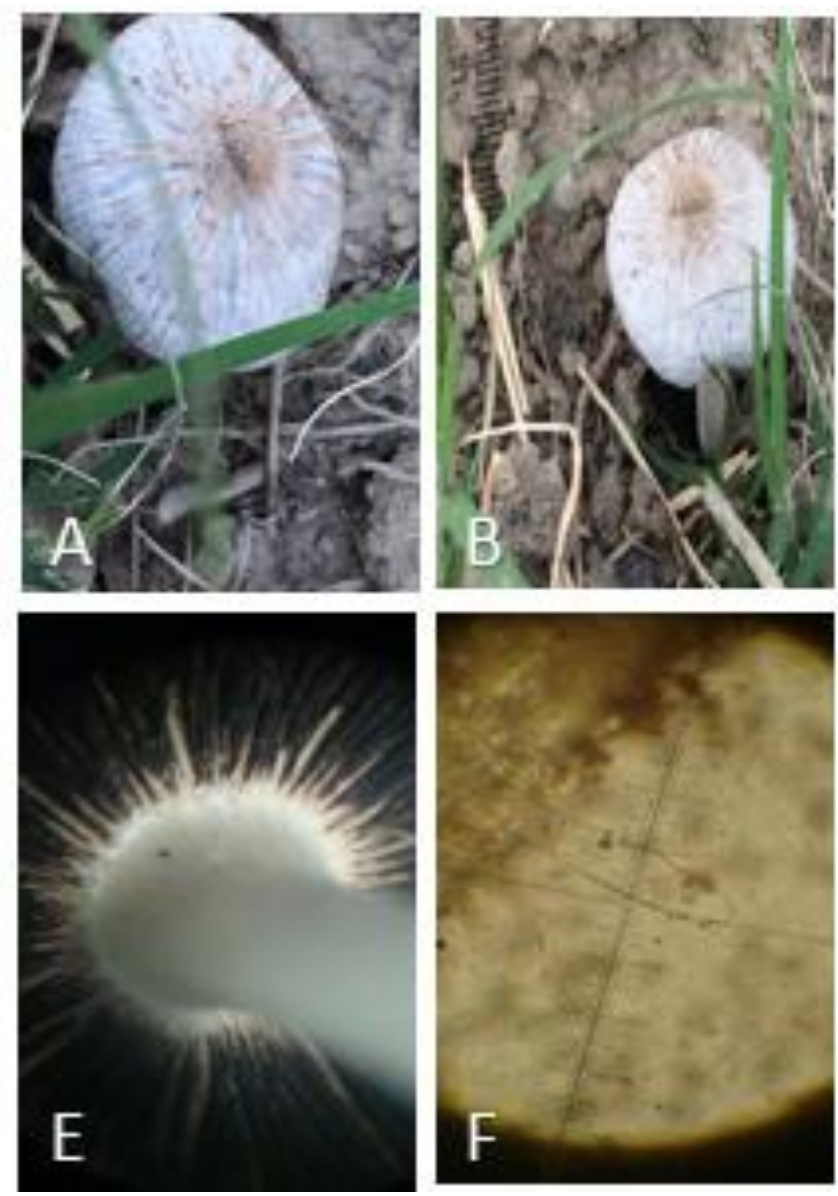

Fig. 6: $P$. plicatilis.
cystidia; H, spores.

\section{Species : Psathyrella candolleana (Fr.) Maire} (Fig. 7).

Macroscopic features: Cap up to $7 \mathrm{~cm}$ wide, conic at first then becoming broadly convex or flate, margin with white partial veil remnants when young, upturned, often cracked, with brown or light brown disc, hygrophanous, smooth, beige, light brown or nearly white. Gills: attached to the stem or free, close or crowded, white or light brown when young, brown to dark brown in age. Stipe: up to $8 \mathrm{~cm}$ tall, $0.3-0.7 \mathrm{~cm}$ thick, nearly solid when young, hallow in age, cylindrical, white, central.

Microscopic features: Basidia: 4-spored, 25-32 $\times$ $10 \mu \mathrm{m}$. Spores $7-8.5 \times 3.5-5 \mu \mathrm{m}$, elliptical with
Alberto, 2012) and some countries bordering Iraq like Turkey (Sesli and Denchev, 2008).
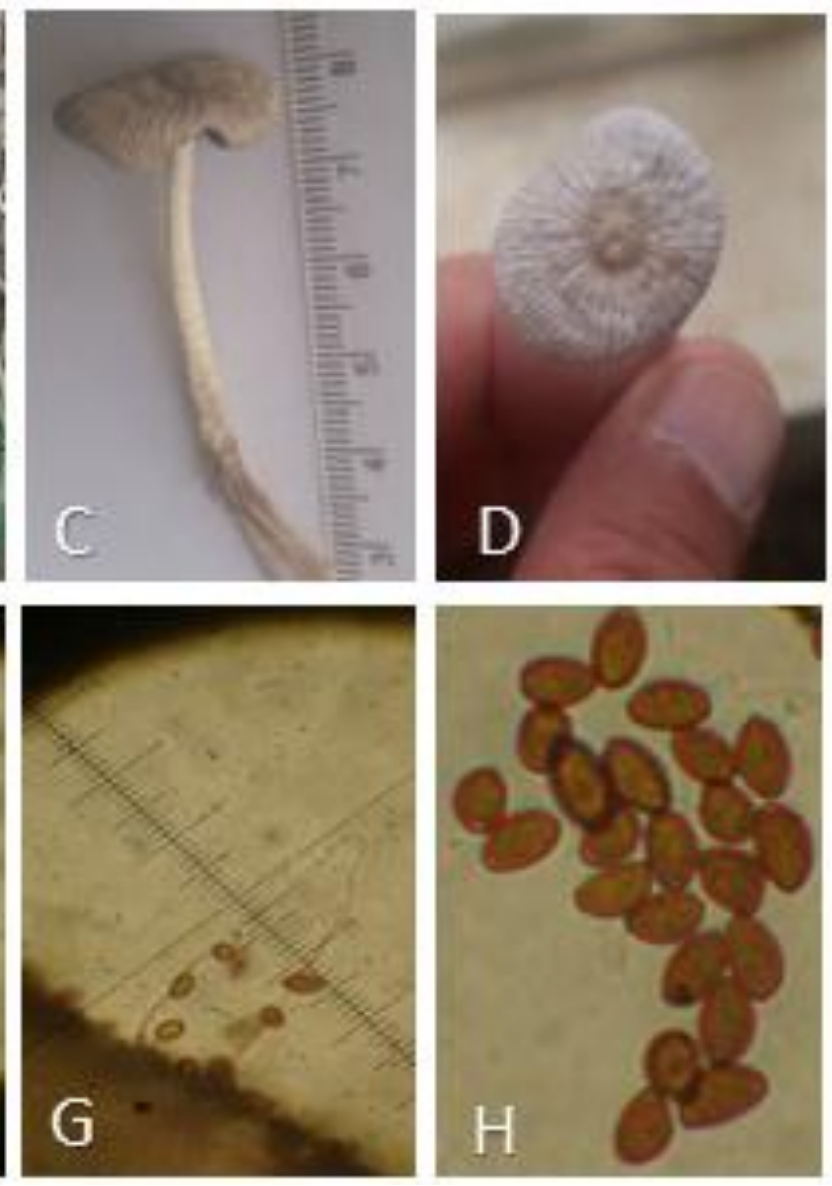

truncated end, smooth, brown. Spore print purple brown. Pleurocystidia absent, cheilocystidia many, subatriform, clavate, subclavate. Habit and habitat: singly or gregarious in grassy areas or in gardens and cultivated areas. Tikrit University campus. Spring-Winter. P. candolleana was first reported fom Iraq (in subarid region of Aljazira) by Al- Habib et al. (2014). The present paper reports this species for the first time from Tikrit district / Salahadin Governorate-North central Iraq. $P$. candolleana was reported from North America (Kuo, 2011 a, b), Iran (Karim and Kavosi, 2013), Turkey (Sesli and Denchev, 2008), Poland (Luszczynski, 2007), Greece (Polemis et al., 2012), Pakistan (Razaq et al., 2014), Argentina (Niveiro and Alberto, 2012) and India (Gogoi and Parkash, 2015). 

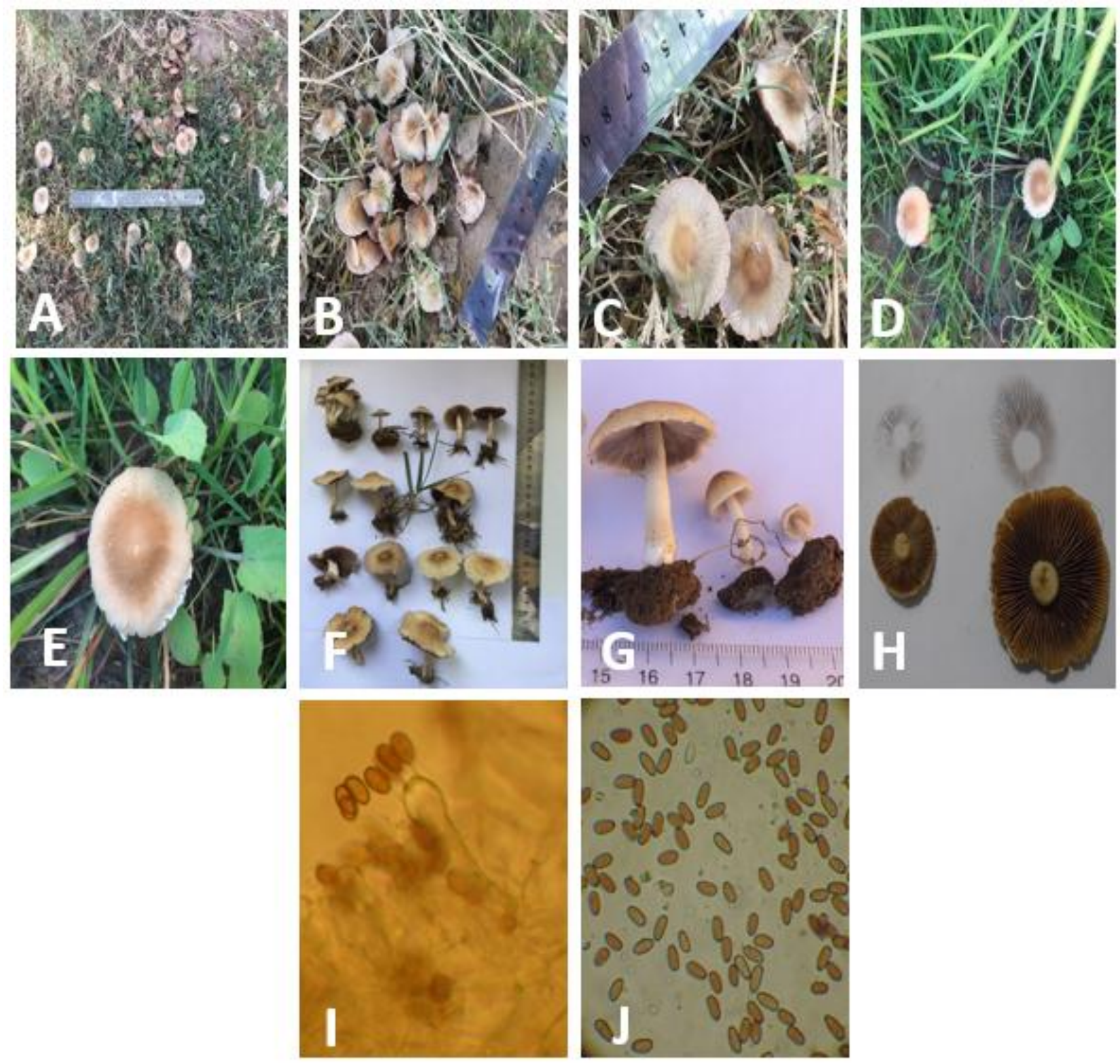

Fig. 7: P. candolleana. A-E, fruiting bodies in habitat; F,G, fruiting bodies in lab.; $\mathrm{H}$, gills and spore print; I, basidium; J, spores.

\section{Species : P. spadiceogrisea (Schaeff.) Maire} (Fig. 8)

Macroscopic features: Cap up to $7 \mathrm{~cm}$ wide, convex, conical, bell-shaped, flat-cone at maturity, margin finely lined, brown to yellow brown or gray brown. Gills: attached to the stipe, close or slightly distant, first white becoming dark brown. Stipe: up to $7 \mathrm{c} \mathrm{m}$ tall, up to $0.5 \mathrm{~cm}$ thick, cylindrical, slightly tapered near the apex, mostly bald, white, hallow. Spore print dark brown with purple shade.

Microscopic features: Basidia: 4- spored, 20- $30 \times$ 7.5-10 $\mu \mathrm{m}$, Spores: $6.25-10 \times 3-5 \mu \mathrm{m}$, ellipsoidal oval, subcylindrical, often with truncate end,smooth, brown. Cheilocystidia, capitate, cylindrical, utriform 30-45 $\times 12.5-15 \mu \mathrm{m}$, pleurocystdia utriform. Habit and habitat: Solitary or gregarious on stumps. Tikrit city/ Salahadin Governorate. Spring-Summer. Suliaman et al. (2017) reported this species from Iraqi Kurdistan (Northern Iraq) and the present paper reports this 
fungus for the first time from Salahadin Governorate / Tikrit district/ central Iraq. $P$. spadiceogrisea was reported from North America
(Kuo, 2011c), Turkey (Sesli and Denchev, 2008), Poland (Luszczynski, 2007), Serbia (Vukojevic et al., 2016) and Cameron (Kinge et al., 2013).
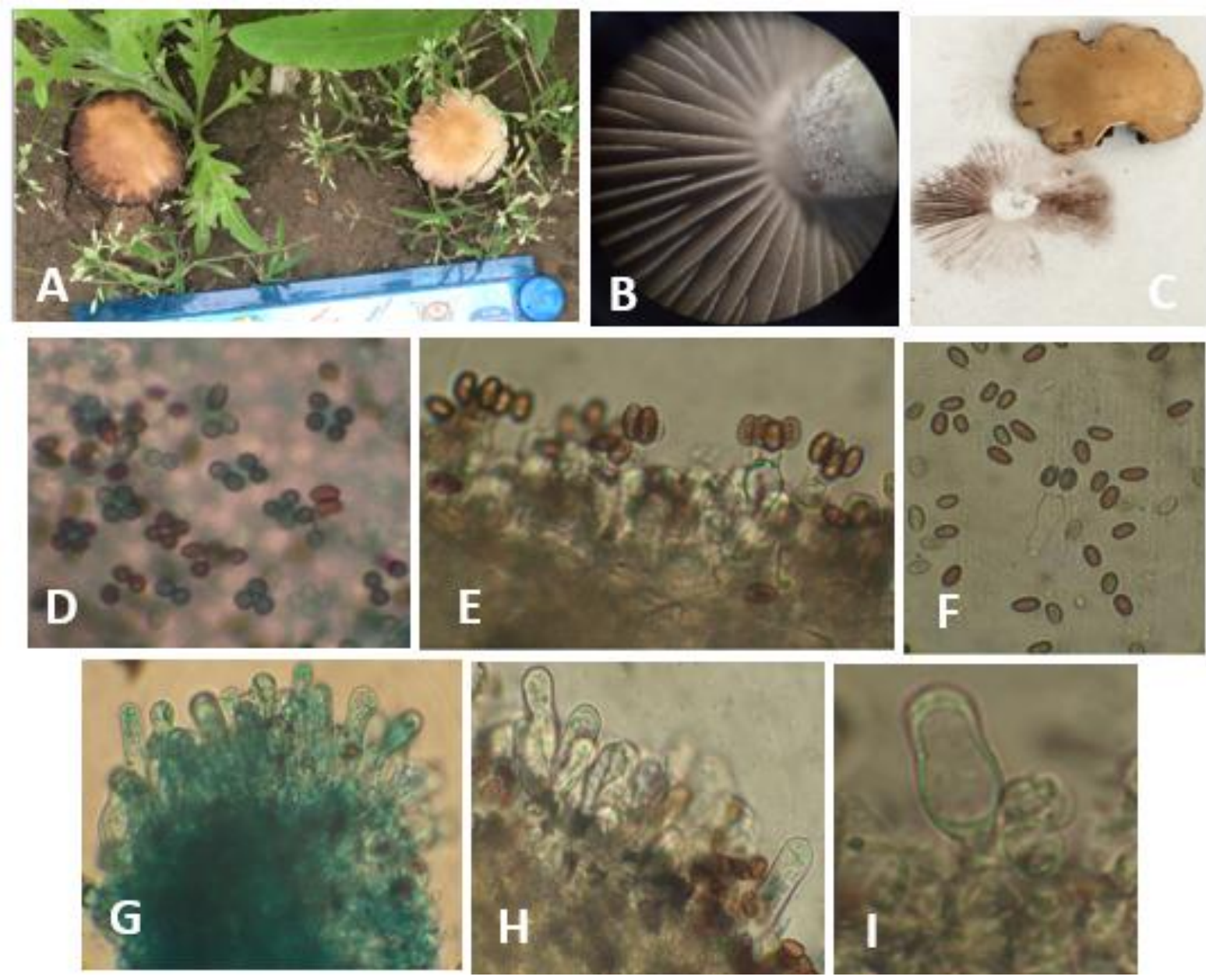

Fig. 8: P. spadiceogrisea. A, fruiting bodies in habitat; B, gills; C, spore print; D,E, basidia; F, spores and basidium; G, H, cheilocystidia; I, pleurocystidia.

\section{Family: Strophariaceae}

Species: Agrocybe praecox (Pers.) Fayod (Fig. 9).

Macroscopic features: Cap 1-5 cm across, convex when young then becoming broadly convex, smooth at first, showing white cracks in age, when young white veil remnants are visible on the margin, brown. Gills: attached, close, initially white and covered by a white partial veil, brown in age. Stipe: up to $7 \mathrm{~cm}$ long, $1.5 \mathrm{~cm}$ thick, white, equal, smooth, sold, with white ring. Flesh white. Spore print brown.
Microscopic features: Basidia: 4-spored, spores 7.5-11 × 5-7 $\mu \mathrm{m}$, ellipsoid, smooth. Habit and habitat: saprotrophic, gregarious on wood debris (under apple and willow trees). Spring, summer and autumn. Locality: Al-Alam city and Dujail area(Dujail district). A. praecox was reported for the first time from Northern Iraq by Suliaman et al. (2017) and here is the first report on this species from two districts, Dujail and Tikrit, from Salahadin Governorate. This fungus was reported from North America (Kuo, 2006), Europe and North Africa (Courtecuisse and Duhem, 1994), Turkey (Sesli and Denchev, 2008) and Netherlands (Noordeloos et al., 2005). 

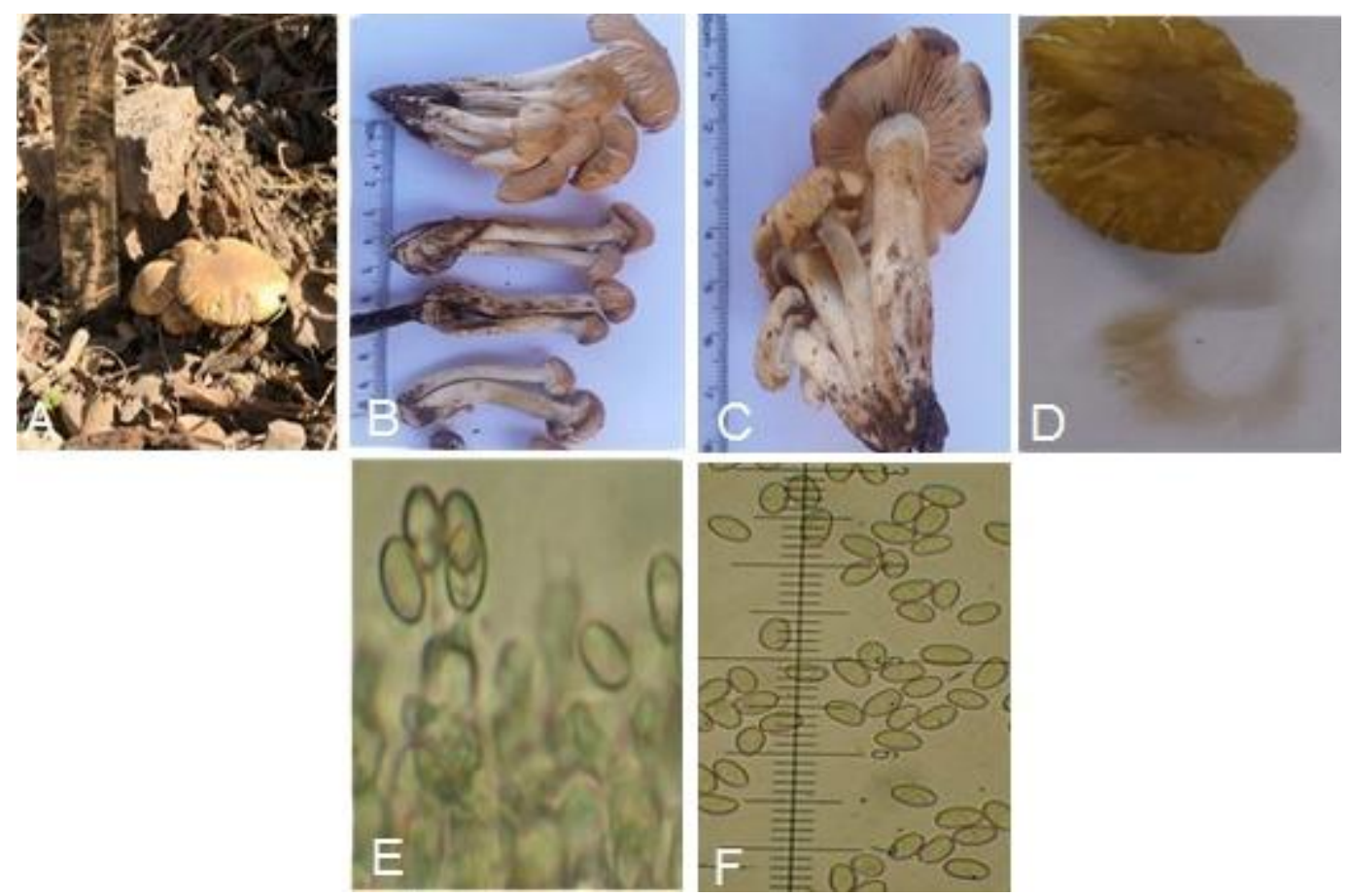

Fig. 9: A. praecox. A, fruiting bodies in habitat; B, C, fruiting bodies in lab.; D, spore print; E, basidium; F, spores.
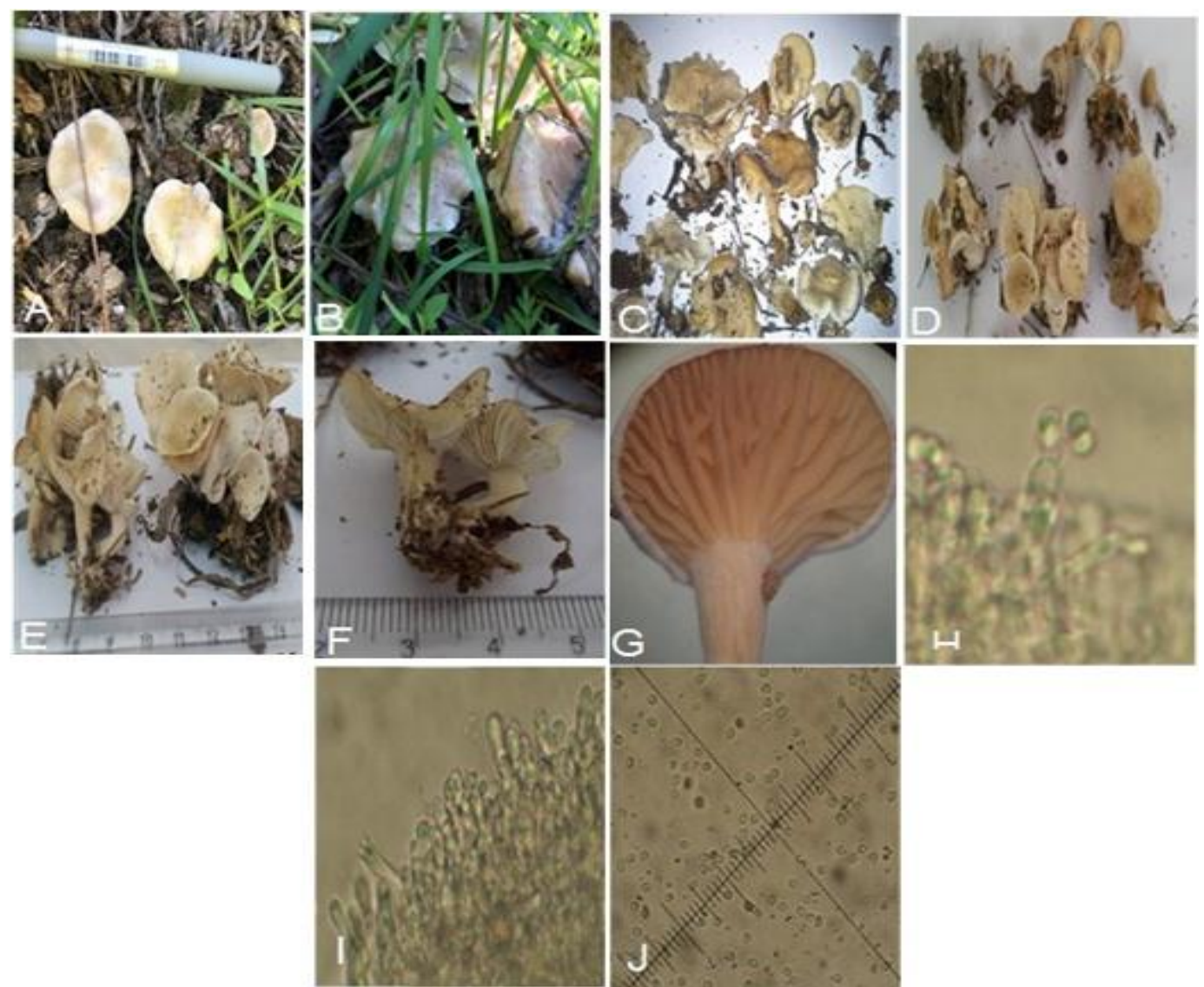

Fig. 10: C. flavidella. A, B, fruiting bodies in habitat; C-F, fruiting bodies in lab.; G, gills; H, I, basidium; J, spores. 


\section{Family: Tricholomataceae}

Species: Clitocybe flavidella (Peck) Sacc. (Fig. 10).

Macroscopic features: Cap 1-3 cm across, smooth, white, cream, off-white, convex with enrolled margin at first, flat with center depressed in age. Gills: attached or run down the stipe, close, white. Stipe: $1-3 \mathrm{~cm}$ long, 0.3-0.8 cm thick, white, central, equal, hollow.

Microscopic features: Basidia: $25 \times 5 \mu \mathrm{m}, 4-$ spored, spores 3.5- $5 \times 2.5-3.75 \mu \mathrm{m}$, ellipsoidal, sobglobose, smooth. Cystidia absent. Clampconnections present. Habit and habitat: saprobic, gregarious, on decayed fallen leaves near rotting wood under willow trees. Al- Alam -Defsha village. January - April. This is the first report of $C$. flavidella from Iraq. Reports on this fungal species are not available from countries bordering Iraq.

\section{Order: Polyporales}

\section{Family: Polyporaceae}

Species: Lentinus tigrinus (Bull.) Fri. (Fig. 11).
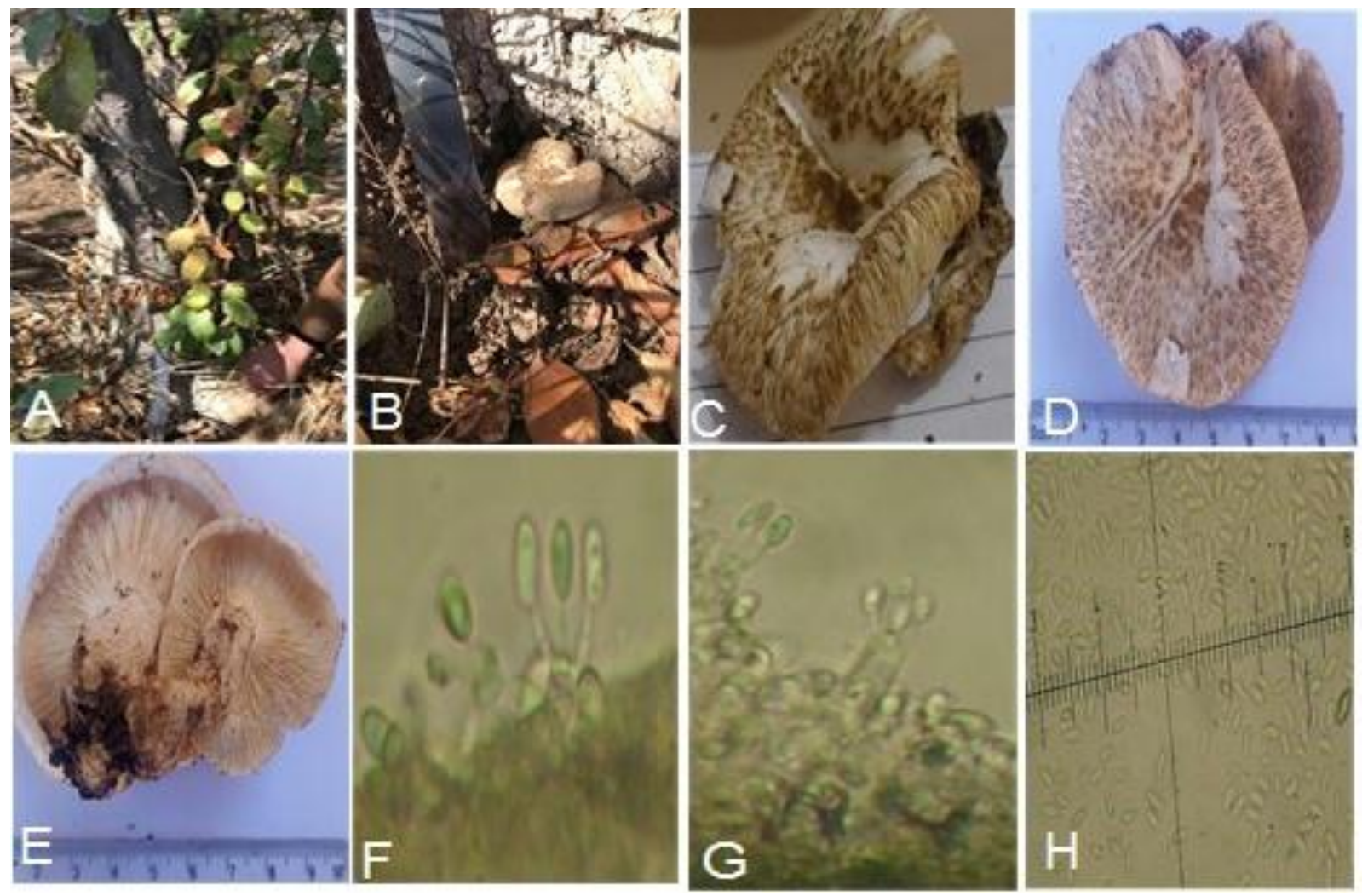

Fig. 11: L. tigrinus. A, B, fruiting bodies in habitat; C-E, fruiting bodies in lab.; F, G, basidia; H, spores.

Macroscopic features: Cap up to $7 \mathrm{~cm}$ across, convex, broadly convex to funnel -shaped, with central depression, incurved margin, covered with brown scales and hairs. Gills decurrent, crowded, white. Stipe: up to $4 \mathrm{~cm}$ long, up to $1 \mathrm{~cm}$ thick, central or eccentric, tapering toward the base, sometimes bent, white with brown scales similar to those on the cap, solid. Microscopic features : Basidia 4- spored, spores 6.25-8.75 X 2.5- 4.o $\mu \mathrm{m}$, cylindric,ellipsoidal, sometimes with a fine nipple, smooth. Cheilocystidia and pleurocystidia not distinguised.Habit and habitat: Saprotrophic, solitary or clustered on the streambank trees (like apple and willow trees). December-February. Locality: orchards in Dujail city/ Dujail district. This fungus was first reported in Iraqi Kurdistan(North of Iraq) by Suliaman et al.(2017). L.tigrinus was found in USA (Kuo,2017), Turkey 
(Sesli and Denchev, 2008), Iran (Shahtahmasebi et al., 2017), India (Gogoi and Parkash, 2015) and Cameroon (Kinge et al., 2013).

\section{Conflict of interest statement}

Author declares that here is no conflict of interest.

\section{References}

Adhikari, M.K., 2014. Psathyrella candolleana (FR.:FR.) Maire var candolleana (FR.) Maire: A new record of mushroom for Nepal. Scient. World. 12(12), 77-78.

Ajana, M., Ouabbou, A., Elkholfy, S., Nmichi, A., Ouazzani Touhame, A., Benkirane, R., Douira, A., 2017. Some new observations on the Volvariella genus Speg. 1898. Int. J. Agric. Environ. Biotechnol. 2(2), 940-945.

Al- Habib, M.N., Holliday, J.C., Tura, D., 2014. The pale brittle stem mushroom, Psathyrella candolleana (higher Basidiomycetes): An indigenous medicinal mushroom new to Iraq. Int. J. Med. Mushroom. 16(6), 617- 622.

Amandeep, K., Atri, N.S., Munruchi, K., 2015. A checklist of coprophilous agarics of India. Curr. Res. Environ. Appl. Mycol. J. Fungal Biol. 5(4), 322-348.

Bates, S.C., 2006. A preliminary checklist of Arizona macrofungi. Canotia. 2(2), 47-78.

Chang, S., Miles, G.P., 2004. Mushrooms: Cultivation, nutritional value, medicinal effects and environmental impact. CRC Press, 436p.

Courtecuisse, R., Duhem, B., 1994. Guide des champignons de France et d Europe. Delachaux et Niestle. P360. ISBN 0- 340-00953-2.

De Silva, D.D., Rapior, S., Sudarman, E., Stadler, M., Xu, J., Alias, S.A., Hyde, K.D., 2013. Bioactive metabolites from macrofungi: ethnopharmacology, biological activity and chemistry. Fungal Divers. 62, 1- 40.

Desjardin, D.E., Wood, M.G., Stevens, F.A., 2015. California Mushroom: The comprehensive Identification Guide. Timber Press: Portland, OR.560p.

Devi, D., Shrivastava, K., 2016. Diversity of macrofungi in Jalukbari reserve forest of
Kamrup district, Assam. Adv. Appl. Sci. Res. 7(1), 115-119.

Fadavi, S., Abbasi, S., Asef, M.R., 2015. A contribution to the identification of agaric fungi of Kermanshah, W $\operatorname{Iran}(2)$ : Families Agaricaceae, Inocybaceae, Pluteaceae and Polyporaceae. Rostaniha. 16(1), 1-16.

Florea, A. R., Comandini, O., Rinaldi, A.C., 2012. A preliminary checklist of macrofungi of Guatemala, with notes on edibility and traditional knowledge. Mycosphere 3(1), 1-21.

Gadd, G. M., 2001. Fungi in bioremediation, United Kingdom, Press syndicate of the University of Cambridge. pp.1-24.

Gerhardt, E., 1996. Taxonomische revision der gattungen Panaeolina (Fungi, Agaricales, Coprinaceae). Biblioth. Bot. 147, 1-149.

Gogoi, G., Parkash, V., 2015. A checklist of gilled mushrooms (Basidiomycota : Agaricomycetes) with diversity analysis in Hollongapar Gibbon wildlife sanctuary, Assam, India. J. Threat. Taxa. 7 (15), 8272-8287.

Hawksworth, D.L., Kirk, P.M., Sutton, B.C., Pegler, D.N., 1995. Ainsworth and Bisbys Dictionary of fungi. CAB Intl. 616p.

Justo, A., Vizzini, A., Minnis, A.M., Menolli, Jr. N., Capelari, M., Rodriguez, O., Malysheva, E., Contu, M., Ghingnone, S., Hibbett, D.S., 2011. Phylogeny of the Pluteaceae (Agaricales, Basidiomycota) taxonomy and character evolution. Fungal Biol. 115, 1-20.

Karim, M., Kavosi, M.R., Hajizadeh, G., 2013. Macrofungal community in Hyrcanian forests, north of Iran: Relationships with season and forest types. Ecol. Balkan. 5(1), 87-96.

Kaur, A., Atri, N. S., Kaur, M., 2014. Diversity of coprophilous species of Panaeolus (Psathyrellaceae, Agaricales) from Punjab, India. Biodivers. 15(2), 115-130.

Keirle, M.R., Hemmes, D.E., Desjardin, D.E., 2004. Agaricales of the Hawaiin Islands. 8. Agaricaceae: Coprinus and Podaxis; Psathyrellaceae: Coprinopsis, Coprinellus and Parasola. Fungal Divers. 15, 33-124.

Kinge, T.R., Egbe, E. A., Tabi, E.M., Nji, T.M., Mih, A. M., 2013. The first checklist of macrofungi of Mount Cameroon. Mycosphere. 
4(4), 694-699.

Kuo, M., 2004, November. Volvariella speciosa. Retrieved from the MushroomExpert.ComWeb site: http://www.mushroomexpert.com/volvarella -speciosa.html.

Kuo, M., 2006, September. Agrocybe praecox. Retrieved from the MushroomExpert.ComWeb site: http://www.mushroomexpert.com/agrocybepraecox.html

Kuo, M., 2007, February. Panaeolus papilionaceus. Retrieved from the MushroomExpert.ComWeb site: http://www.mushroomexpert.com/ panaeolus-papilionaceus.html

Kuo, M., 2008, February. Coprinopsis romagnesiana. Retrieved from the Mushroom Expert.ComWeb site: http://www.mushroom expert.com/ coprinopsis-romagnesiana.html.

Kuo, M., 2010, May. Clitocybe flavidella. Retrieved from the MushroomExpert.Com Web site: http://www.mushroomexpert.com/ clitocybeflavidella.html

Kuo, M., 2011a, January. The genus Psathyrella.Retrieved from the Mushroom Expert.ComWeb site: http://www.mushroom expert.com/psathyrella.html.

Kuo, M., 2011b, January. Psathyrella candolleana. Retrieved from the MushroomExpert.Com Web site: http://www.mushroomexpert.com/ psathyrella-candolleana.html.

Kuo, M., 2011c, January. Psathyrella spadiceogrisea. Retrieved from the MushroomExpert.Com Web site: http://www.mushroomexpert.com/psathyrellaspadiceogrisea.html.

Kuo, M., 2011 February. Parasola plicatilis. Retrieved from the MushroomExpert.Com Web site: http://www.mushroomexpert.com/ parasola-plicatilis.html

Kuo, M., 2017, December. Lentinus tigrinus. Retrieved from the MushroomExpert.Com Web site: http://www.mushroomexpert.com/lentinustigrinus.html.

Lee, J.S., Kim, C., Choi, S.Y., Lee, H.B., 2017. Eight previously unreported species of macrofungi from Korea. Kor. J. Mycol. 45(4), 362-369.

Luszczynski, J., 2007. Diversity of Basidiomycetes in various ecosystems of the Gory Swietokrzyskie MTS. J. Polish Bot. Soc. 97, 1210.

Melzer, A., 2017. Kyhnaer Hauptstrabe 5,04509 Wiedemar, Germany, http://www.vielepilze.de/ Key to Psathyrella and related species.

Mohammed, N., Shinkafi, S.A., Enagi, M.Y., 2017. Isolation of coprophilous mycoflora from different dung types in some local government areas of Niger states, Nigeria. Am. J. Life Sci. 5 (3-1), 24-29.

Mueller, G.M., Schmit, J.P., Leacock, P.R., Buyck, B., Cifuentes, J., Desjardin, D.E., Halling, R.E., Hjortstam, K., Iturriaga, T., Larsson, K.H., Lodge, D.J., May, T.W., Minter, D., Rajchenberg, M., Redhead, S.A., Ryvarden, L., Trappe, J.M., Watling, R., Wu, Q., 2007. Global diversity and distribution of macrofungi. Biodivers. Conserv. 16, 37-48.

Mueller, G.M., Bills, G.F., 2004. Introduction. In: Biodiversity of Fungi: Inventory and Monitoring Method (Eds.: Mueller, G.M., Bills, G. F., Foster, M.S.). Elsevier Academic Press, San Diego. 777p.

Niveiro, N., Alberto, E., 2012. Checklist of Argentine Agaricales 2. Coprinaceae and Strophariaceae. MycotaxonLink Page 120: 505.

Noordeloos, M.E., Kuyper, T. H.W., Vellinga, E.C., 2005. Flora Agaricina Neerlandica: Critical Monographs on Families of Agarics and Boleti Occurring in the Netherlands, Vol.6. CRC Press.

OReilly, P., 2016. Fascinated by Fungi: Exploring the History, Mystery, Facts and Fiction of the Underworld Kingdom of Mushrooms. First Nature, 443p.

Polemis, E., Dimou, D.M., Tzanoudakis, D., Zervakis, G.I., 2012. Annotated checklist of Basidiomycota (Subclass Agaricomycetidae) from the islands of Naxos and Amorgos (Cyclades, Greece). Ann. Bot. Fenn. 49, 145-161.

Razaq, A., Shahzad, S., Ali, H., Noor, A., 2014. New reported species of macrofungi from Pakistan. J. Agri-Food Appl. Sci. 2(3), 67-71.

Redhead, S.A., 1997. Macrofungi of British Columbia: Requirement for Inventory. Res. Br., B.C. Min. For., and Wildl. Br., B.C.Min. 
Environ., Lands and Parks, Victoria, B.C.Work. Pap.28/1997.

Richardson, M.J., Watling, R., 1997. Keys to fungi on dung. British Mycological Society, PO Box30, Stourbridge, West Midlands DY9 9PZ.

Schafer, D.J., 2010. Keys to sections of Parasola, Coprinellus, Coprinopsis and Coprinus in Britain. Field Mycol. 11(2), 44-51.

Sesli, E., Denchev, C.M., 2008. Checklists of the myxomycetes, larger ascomycetes and larger basidiomycetes in Turkey. Mycotaxon. 106, 6567.

Shahtahmasebi, S., Pourianfar, H.R., Rezaeian, S.,
Janpoor, J., 2017. A preliminary study on cultivation of Iranian wild growing medicinal mushroom Lentinus tigrinus. Int. J. Farm. Allied Sci. 6(6), 149-153.

Suliaman, S.Q., Al-Khesraji, T.O., Hassan, A., 2017. New records of basidiomycetous macrofungi from Kurdistan region - Northern Iraq. Afr. J. Plant Sci.11(6), 209-219.

Vukojevic, J., Hadzic, I., Knezevic, A., Stajic, M., Milovanovic, I., Cilerdzic, J., 2016. Diversity of macromycetes in the Botanical Garden (Jevremovac) in Belgrade. Bot. Serb. 40(2), 249-259.

\section{How to cite this article:}

Al-Khesraji, T. O., 2018. Ten previously unreported Basidiomycota macrofungi from Salahadin Governorate including five new records to Iran. Int. J. Curr. Res. Biosci. Plant Biol. 5(6), 11-24. doi: https://doi.org/10.20546/ijcrbp.2018.506.002 